\title{
Analysis of Leading Metal (Pb) and Cadmium (Cd) Content Green Shells (perna viridis L.) in the Kreneng Market
}

\author{
A. A. Istri Mirah Dharmadewi
}

\author{
Mahadewa University, Denpasar, Bali, Indonesia
}

\begin{abstract}
This research was conducted to determine the content of heavy metals lead $(\mathrm{Pb})$ and Cadmium $(\mathrm{Cd})$ in green shells circulating in the kreneng market. Samples of green shells were taken from the kreneng market, Bali. Then analysis of the content of lead $(\mathrm{Pb})$ and Cadmium $(\mathrm{Cd})$ in the Analytical Laboratory of Udayana University. Samples of green mussels (Perna viridis L.) Were opened from the shell to take the meat. Furthermore, the sample is mashed by chopping and pounding and put into erlenmeyer. Each sample was given 3 repetitions using the factorial pattern RAL. Then with a wet ashing process (wet destruction). The results showed that the heavy metal content of lead and cadmium in green mussels (Perna viridis L.) Exceeded the maximum limit of heavy metal contamination. The heavy metal content of lead $(\mathrm{Pb})$ shellfish taken at the Kreneng Market is 29.595 $\mathrm{mg} / \mathrm{kg}$ while the heavy metal content of cadmium (Cd) taken at the Kreneng market is $3.41 \mathrm{mg} / \mathrm{kg}$ the result of the heavy metal content analyzed exceeds the predetermined by the Food and Drug Supervisory Agency (BPOM).
\end{abstract}

Keywords: Metals $(\mathrm{Pb})$, Cadmium $(\mathrm{Cd})$, Green Shells, Kreneng Market

*Corresponding Author:

E-mail: mirahdharmadewi@gmail.com (A.A. Istri Mirah Dharmadewi)

Mahadewa University, Bali, Indonesia

\section{INTRODUCTION}

Green shellfish (Perna viridis L.) is a marine biota that can be cultivated and is environmentally friendly because in the cultivation process it does not require feed. The use of shellfish as a source of food is quite popular among Indonesians, especially those who live around the coast. The part of the shell that is eaten is the meat, including the digestive tract of food. Shellfish are used as a substitute for meat, poultry, eggs, etc. (Jalaluddin and Ambeng, 2005). Shellfish is a source of high-quality protein, which is equivalent to other animal protein sources. Besides being used as a source of protein, shellfish can be used as a bioindicator because they have filter feeder properties (take their food by filtering water) and are sessile (settling) so that they are able to absorb heavy metal contamination in the environment contaminated by heavy metals so that naturally heavy metals accumulate in the body. shellfish which means that all the dissolved and undissolved raw material components will enter the green shells body. Some of the dangerous heavy metals are mercury or mercury $(\mathrm{Hg})$, cadmium $(\mathrm{Cd})$, lead $(\mathrm{Pb})$, copper $(\mathrm{Cu})$, and others (Darmono, 2001). Heavy metals that pollute marine waters are $\mathrm{Pb}$ and $\mathrm{Cd} . \mathrm{Pb}$ metal can enter the body through respiration, food and drink. $\mathrm{Pb}$ metal is not needed by humans, so when food is contaminated by this metal, the body will partially excrete it.

The higher the levels of heavy metals in a waters, the higher the levels of heavy metals that accumulate in the bodies of the aquatic animals that live in them. If consumed, heavy metal poisoning can endanger the health of lungs, bones, liver, reproductive glands, and kidneys (Wibisono , 2005). Kreneng market is a 
sales center for various types of sea catches that will be consumed by the people of Denpasar. One of the catches of fishermen that will be sold in the market is shellfish. The shells on the market must have safety for consumption by the public and the heavy metal content must be considered so as not to disturb public health with the dangers that will be caused by these heavy metals.

Based on the above background heavy metal pollution is a problem of environmental pollution that needs attention so that research is carried out on the analysis of the heavy metal content of lead $(\mathrm{Pb})$ and Cadmium $(\mathrm{Cd})$ in green mussels (Perna viridisL.) so that it can be used in monitoring environmental pollution and food safety, and exposure to the heavy metals lead $(\mathrm{Pb})$ and cadmium (Cd) to the community is important considering that marine biota can be used as a material for human consumption.

\section{METODS}

\subsection{Research Time and Location}

This research will be conducted from January to December 2019. Sampling was carried out in Kreneng Market. Meanwhile, the analysis of the heavy metal content of lead $(\mathrm{Pb})$ and cadmium $(\mathrm{Cd})$ was carried out at the UPT (Integrated Service Unit) Analytical Laboratory of Udayana University.

\subsection{Sampling Technique}

The sampling method was carried out by purposive sampling, also known as consideration sampling, where the sample was determined on the basis of the consideration that the sample taken could represent the population (Sudjana, 2009). The sample used in the study was a species of green clam (Perna viridis L.) which was taken directly from the Kreneng Market
Samples were taken from 2 traders in each market as much as $1 \mathrm{~kg}$ then decomposited so that it becomes 1 sample for each market. Samples were taken in good and fresh conditions and then stored in an ice box that already contained dry ice. Then the sample was analyzed at the Analytical Laboratory of Udayana University

\subsection{Analysis Procedure}

\subsubsection{Sample Preparation}

Samples of green mussels (Perna viridis L.) were opened from their shells to take the meat. Furthermore, the sample is mashed by chopping and pounding and put into Erlenmeyer. Each sample was given 3 repetitions. Then proceed with the wet digestion process.

\subsubsection{Wet Washing Process}

The sample was weighed approximately 0.5 grams using analytical scales then put into the digestion flask then added $2 \mathrm{ml}$ of concentrated $\mathrm{H} 2 \mathrm{SO} 4$ solution and $10 \mathrm{ml}$ of HNO3. The sample solution is heated slowly until it is dark. 1 $2 \mathrm{ml}$ of $\mathrm{HNO} 3$ was added and continued heating until the solution was darker than before. Followed by adding HNO3 little by little until the solution is not dark, then cooled. $10 \mathrm{ml}$ of distilled water was added to the solution and heated again to produce a colorless vapor. The solution is allowed to cool down then diluted with distilled water to a volume of $100 \mathrm{ml}$. The sample was read using an AAS (Atomic Absorption Spectrophotometry) tool.

\subsubsection{Determination of Lead $(\mathrm{Pb})$ and Cadmium ( $\mathrm{Cd}$ ) Content}

The determination of the heavy metal content of Lead $(\mathrm{Pb})$ and Cadmium $(\mathrm{Cd})$ in the sample is determined by a calibration curve technique that is similar to a linear line so that the sample concentration can 
be determined from the measured absorbance. After the measurement concentration is known, the actual content in the sample can be determined by calculation.

Heavy metal analysis was carried out using atomic absorption spectrophotometri (AAS), namely by using a principle based on the Lambert-Beert Law, namely the amount of light absorbed is directly proportional to the content of the substance. The line equation between heavy metal concentration and absorbance is a linear equation with a positive coefficient of direction, namely $\mathrm{Y}=\mathrm{a}+$ $\mathrm{bX}$. By entering the absorbance value of the sample solution into the standard solution line equation, the sample heavy metal content can be known (Hutagalung et al., 1997).

The sample solution containing metal ions is passed through an air-acetylene flame at $2000 \mathrm{oC}$, causing evaporation and some of it is reduced to atoms. The very strong cathode lamp gives off energy at a certain wavelength and will be absorbed by the heavy metal atoms being analyzed. The amount of light energy absorbed by heavy metal atoms at this particular wavelength is proportional to the amount of substance vaporized as it passes through an airacetylene flame. Each heavy metal element requires a different cathode lamp. The entire procedure is very sensitive and selective because each element requires a very definite wavelength.

\subsubsection{Research Design}

The research design used in this study was a randomized block design (RBD) with 2 treatment factors, namely 2 types of heavy metals and each treatment consisting of 5 repetitions.

\subsubsection{Data Analysis}

According to (Sudjana, 2009) the levels of lead and cadmium obtained from the measurement results of each sample solution were analyzed descriptively in the form of tables and figures because in this study the aim was to determine the state of the research object and to get the meaning of the implications based on the description of the research object. Then proceed statistically usingANOVA (Analysis of Variance).

From the ANOVA test results that were significantly different $(\mathrm{P}<0.05)$ followed by the Duncan test to see the differences between treatments.

\section{RESULT AND DISCUSSION}

\subsection{Sample Weight of Green Shells (Perna} viridis $L$.)

The results of the sample weight of green mussels that have been weighed using analytical scales can be seen in table 3.1.1 below:

\begin{tabular}{|c|c|c|}
\hline Lokasi & Kode Sampel & Berat \\
\hline $\begin{array}{c}\text { Pasar } \\
\text { Kreneng }\end{array}$ & K1 & 0,5203 \\
\hline & K2 & 0,6079 \\
\hline & K3 & 0,5937 \\
\hline
\end{tabular}

\subsection{Analysis of the Content of Lead (Pb)} and Cadmium (Cd) Heavy Metals

The results of the analysis of the heavy metal content of lead $(\mathrm{Pb})$ and cadmium $(\mathrm{Cd})$ in green mussel samples

purchased at Badung and Kreneng markets using AAS (Atomic Absorption Spectrophotometery) can be seen in the table below:
Journal Homepage:

http://ejournal.undwi.ac.id/index.php/jsds
Copyright (C) 2020 Dwijendra University. All right reserved. 
Table 1.

Results of Analysis of Lead $(\mathrm{Pb})$ Content in Green Shells

Results
\begin{tabular}{|c|l|l|c|c|}
\hline No. & \multicolumn{1}{|c|}{ Parameter } & Methods & Unit & Result \\
\hline & Kreneng Market & & $\mathrm{kg}$ & \\
\hline 1. & Green Shels & Spektrometri & $\mathrm{mg} / \mathrm{kg}$ & 32,476 \\
\hline 2. & Green Shels & Spektrometri & $\mathrm{mg} / \mathrm{kg}$ & 25,764 \\
\hline 3. & Green Shels & Spektrometri & $\mathrm{mg} / \mathrm{kg}$ & 30,545 \\
\hline
\end{tabular}

Note: sign $=$ not detected at device detection limit $<0.001 \mathrm{mg} / \mathrm{L}$

Table 2.

Results of Analysis of Cadmium (Cd) Content in Green Shells

\begin{tabular}{|c|l|c|c|c|}
\hline $\begin{array}{c}\text { No. } \\
\text { No. }\end{array}$ & \multicolumn{1}{|c|}{$\begin{array}{c}\text { Parameter } \\
\text { Parameter }\end{array}$} & $\begin{array}{c}\text { Metode } \\
\text { Methods }\end{array}$ & $\begin{array}{c}\text { Satuan } \\
\text { Unit }\end{array}$ & $\begin{array}{c}\text { Hasil } \\
\text { Result }\end{array}$ \\
\hline & Pasar Kreneng & & $\mathrm{kg}$ & 3,84 \\
\hline 4. & Kerang hijau & Spektrometri & $\mathrm{mg} / \mathrm{kg}$ & 2,87 \\
\hline 5. & Kerang hijau & Spektrometri & $\mathrm{mg} / \mathrm{kg}$ & 3,52 \\
\hline 6. & Kerang hijau & Spektrometri & $\mathrm{mg} / \mathrm{kg}$ & \\
\hline
\end{tabular}

Note: sign $=$ not detected at device detection limit $<0.001 \mathrm{mg} / \mathrm{L}$

From the data above, it can be seen that the heavy metal content of lead and cadmium in green mussels (Perna viridis L.) exceeds the maximum limit of heavy metal contamination. Where the heavy metal content of lead $(\mathrm{Pb})$ of shellfish taken in the kreneng market is $29.595 \mathrm{mg} /$ $\mathrm{kg}$ while the heavy metal content of cadmium $(\mathrm{Cd})$ taken in the kreneng market is $3.41 \mathrm{mg} / \mathrm{kg}$, the result of the heavy metal content analyzed exceeds the threshold normal that has been determined by the Food and Drug Supervisory Agency (BPOM).

According to the theory (Indonesian National Standard) the maximum limit of lead $(\mathrm{Pb})$ contamination in food is $1.5 \mathrm{ppm}$ and the maximum limit of cadmium $(\mathrm{Cd})$ contamination is $1.0 \mathrm{ppm}$. The high levels of cadmium and lead metals found in the Badung market and the kreneng market besides the shells are taken as adults (their body size is bigger) so that the ability to absorb metals is very high and besides that it is also due to community activities that tend to dispose of marine industrial waste. In addition, the source of $\mathrm{pb}$ and $\mathrm{Cd}$ metals in shellfish comes from human activities around the market such as market waste and household waste.

Consume shellfish that contain metal levels that exceed this threshold can cause health problems such as poisoning. Acute poisoning of inorganic lead is now rare. This poisoning is usually caused by inhalation of large quantities of lead oxide in industry or in young children caused by ingestion of paints containing large doses of lead. If lead absorption is slower, abdominal colic and encephalopathy may be present within a few days. Disorders that resemble acute lead poisoning include appenditis, peptic ulcers and pancreatitis.

The most commonly seen characteristics of chronic heavy metal poisoning such as lead and cadmium are 
weakness, anorexia, miscarriage, tremors, weight loss, headaches and gastrointestinal symptoms. The association of recurrent abdominal pain and weakness of the moving muscles without pain suggests lead poisoning.

From the research results, it can be seen that the green mussels taken in the kreneng market are not suitable for consumption in large quantities because they contain heavy metals that exceed the predetermined threshold. Green shells are more suitable for cleaning marine environments that have been contaminated with heavy metals. Green shells are able to absorb metals and store them in their bodies effectively, so that green shells are recommended as a heavy metal biofilter and act as a vacuum cleaner for waters contaminated with heavy metals.

\section{CONCLUSIONS}

\subsection{Conclusions}

Based on the results of research and analysis of data that has been done, the conclusions can be drawn as follows :

1. The heavy metal content lead $(\mathrm{Pb})$ of shellfish taken in the market, the heavy metal content taken in the kreneng market is $29.595 \mathrm{mg} / \mathrm{kg}$ while the heavy metal content of cadmium $(\mathrm{Cd})$ is $3.41 \mathrm{mg} / \mathrm{kg}$

2.The results of the analysis of the heavy metal content of lead $(\mathrm{Pb})$ and cadmium $(\mathrm{Cd})$ in green mussels (Perna viridis L.) sold at the Kreneng Market show that the green clams contain heavy metals that have passed the threshold set by the Drug Control Center Food (BPOM).keep the instructions given above, otherwise it will be returned for improvement. Please upload your paper in Microsoft Word (.doc) format file through the journal website under Paper
Submission menu. Papers sent by e-mail will not be processed.

\subsection{Recomendations}

1. So this research is needed regarding other specific heavy metals besides lead and cadmium in green shellfish which are sold in the market.

2. It is necessary to carry out supervision by BPOM and the Health Office of each industry to treat waste before it is discharged into water.

3. It is necessary to conduct socialization about the dangers of consuming foods with heavy metal content of lead and cadmium that exceed the long-term health threshold.

\section{REFERENCE}

Alfian, Zul. (2005). Analysis of Cadmium (Cd) Levels from Shells obtained from the Belawan region by atomic absorption spectrophotometer. Journal of chemical science. Vol 9 No. 2. University of North

Aini, R.T. (2015). "Histopathology of the Liver and Gills of Milkfish (ChanosChanos) Contaminated with Lead Metal $(\mathrm{Pb})$ in Labakkang District, Pangkep Regency". Description.Makassar: Faculty of Veterinary Medicine, Hasanuddin University.

Herto, D.A., Soemirat, J. (2015). Environmental Toxicology. Yogyakarta: Publisher Gadjah Mada University Press

Ika, Tharlir, Irwan, S. (2012). "Analysis of Lead and Iron Metals in Seawater in the Coastal Area of the Taipa Ferry Port, North Palu District." J.akad.chemistry 1 No 4 (November 2012)

Riana, F.L. Anggoro, S. Widowati, I. (2011) Study of heavy metal content in several types of diversity from waters 
in eastern flores regency. Journal of Fisheries 8 No 1.

Jalaluddin, M.N., and Ambeng. (2005) Analysis of Heavy Metals ( $\mathrm{Pb}, \mathrm{Cd}$, and Cr) in Sea Shells (Hiatula chinensisAnadara granosa, and Marcia optima), Marina Chimica Acta, 2 (6): 17-20.

Fernanda, L. (2012). Study of Heavy Metal Content of Lead $(\mathrm{Pb})$, Nickel $(\mathrm{Ni})$, Chromium $(\mathrm{Cr})$, and Cadmium $(\mathrm{Cd})$ in Green Shells (Perna viridis) and Their Fractionation Properties in Marine Sediments. Essay. FMIPA UI.

Parsa, K. (2001) Determination of Pb Content and Spread in Agricultural Soil Around Jalan Raya Kemenuh Village, Gianyar. Description. Chemistry, Udayana University: Denpasar. Not Published

Pigott, G.M .; and B. W., Tucker. (1990). Seafood, Effects of Technology on Nutrition, Pregamon Press, New York

Sudjana. (2009). Statistical Methods. Sixth Edition. Bandung: Tarsito.

Sediaoetama, A.D. (1993). Science of Nutrition. Dian Rakyat Publisher: Jakarta.

Siaka, M., Cris, M. Owen. G. F. Birch. (1998). Evolution Of Some Degestion Method For The Determination Of Heavy Metals In Sediment Sampael By Flame AAs. Analytical Letters, 31 (4).

Supriharyono. (2000). Conservation and Management of Natural Resources in Tropical Coastal Areas. Jakarta: Gramedia Pustaka Utama

Suwignyo, Sugiarti, et al. (2005). Water invertebrates volume I. Jakarta: Selfhelp spreaders

Takarina ND, Bengen DG, Sanusi HS, Riani E. 2013. Geochemical fractionation of copper $(\mathrm{Cu})$, lead $(\mathrm{Pb})$, and zinc $(\mathrm{Zn})$ in sediment and their correlations with concentrations in Bivalve Mollusc Anadara indica from coastal area of Banten Province, Indonesia. Int. J. Mar. Sci. 3(30): 238-243. 